\title{
Determinant factors of anaemia among pregnant women attending antenatal care clinic in Northwest Ethiopia
}

\author{
Tadesse Hailu*, Simachew Kassa², Bayeh Abera', Wondemagegn Mulu and Ashenafi Genanew ${ }^{3}$
}

\begin{abstract}
Background: Anaemia is a low blood haemoglobin concentration and has been shown to be a public health problem affecting both developing and developed countries. Pregnant women are the most vulnerable groups to anaemia due to several factors, including parasitic infection and feeding habits during their pregnancy. The aim of this study was to assess the prevalence and determinant factors of anemia in pregnant women in Northwest Ethiopia.

Methods: A cross-sectional study was conducted among pregnant women from February, 2017 to June, 2017. The data on determinant factors were collected using a structured questionnaire. The hemoglobin level and intestinal parasites were determined using Hemocue HB 201 and formol ether concentration techniques, respectively. Data was entered and analyzed using SPSS version 23 statistical software. Bivariate and multivariate regressions were computed and odds ratio was determined at $95 \%$ confidence interval.

Results: The study consists of 743 participants with a median age of 25 years were included. The prevalence of anemia among pregnant women was 79 (10.6\%). The prevalence of mild, moderate and severe anaemia were 78 (99.8\%), $1(0.1 \%)$ and $1(0.1 \%)$, respectively. Pregnant women of rural dwellers (AOR $=3.72, \mathrm{Cl}=1.51-9.18)$, farmer in occupation ( $A O R=3.51, C l=1.75-7.01)$, and not educated ( $A O R=2.25, C l=1.13-4.48$ ) were significantly associated with increased risk of anemia.

Conclusion: Anaemia is still a problem amongst pregnant women in the study area though much has been done to increase the hemoglobin level during pregnancy. Health education should be given on factors that aggravate anaemia during pregnancy.
\end{abstract}

Keywords: Amaemia, Pregnancy, West Gojjam, Parasitic infection

\section{Introduction}

Anaemia is a condition of lower red blood cells and haemoglobin $(\mathrm{Hgb})$ level than normal [1]. The prevalence of anemia among pregnant women is estimated to be $38 \%$ worldwide, $36.9 \%$ in Africa and $23 \%$ in Ethiopia $[1,2]$. Anaemia can be classified into three catagories, mild, moderate and severe. The Hgb level for each class of anaemia during pregnancy are $10.0-10.9 \mathrm{~g} / \mathrm{dL}$ (mild), $7-9.9 \mathrm{~g} / \mathrm{dL} \quad$ (moderate) and $<7 \mathrm{~g} / \mathrm{dL} \quad$ (severe) [2].

\footnotetext{
*Correspondence: tadessehailu2005@yahoo.com; tadessehailu89@gmail.com ${ }^{1}$ Department of Medical Laboratory Science, College of Medicine and Health Sciences, Bahir Dar University, P.O. Box: 79, Bahir Dar City, Ethiopia Full list of author information is available at the end of the article
}

Generally, pregnant women with $\mathrm{Hgb}$ level $<11 \mathrm{~g} / \mathrm{dl}$ are considered to be anaemic [1].

Several factors might contribute to the causes of anemia among pregnant women. For instance, geohelminth infections during pregnancy may be associated with maternal anaemia. Hookworm is known to be causes of anaemia among pregnant women and hookworm infection mainly aggravates anemia in pregnant women [3]. Infections by geo-helminthes lead to malnutrition, iron deficiency anaemia, and increased vulnerability to other infections in infected pregnant women [4]. The complication may not end up with the maternal anaemia but also causes a complication on the child including; low pregnancy weight gain and intrauterine

(C) The Author(s). 2019 Open Access This article is distributed under the terms of the Creative Commons Attribution 4.0 International License (http://creativecommons.org/licenses/by/4.0/), which permits unrestricted use, distribution, and 
growth retardation, followed by low birth weight and higher perinatal mortality rates [5].

Pregnant woman that live in rural areas [6], lack of raw vegetables in their diet [7], illnesses [6] and low levels of education [8] are also major determinants of anemia.

Malnutrition is also one of the major causes of anaemia among pregnant women in Ethiopia [9]. Working to improve the nutritional status of pregnant women through supplementation of vitamin A, iron, and iodine is important to minimize the risk of anemia [10].

A lot has been done to minimize the risk of anaemia, but the complication of anaemia is still a problem amongst pregnant women especially in a rural set up. The true prevalence and the determinant factors of anaemia were not well addressed in the study area. Therefore, the present study tried to address the stated information gaps so as to give evidence based action.

\section{Methods}

\section{Study design, period and area}

A cross sectional study was conducted from February, 2017 to June, 2017 among pregnant women in West Gojjam Zone, Northwest Ethiopia. The average elevation of the zone is $2,300 \mathrm{~m}$. The annual temperature of the study area ranges between 16.68 to $37.6^{\circ} \mathrm{C}$.

All pregnant women attending antenatal clinic for the first time during the study period were included in the study. Pregnant women undertaking anthelmintic drugs during the data collection time were excluded from the study. Purposive sampling technique was used to include 743 study subjects. The samples were collected in five woredas as of West Gojjam Zone including: Mecha, Debub Achefer, Bure, Jabi-tihinana and Finot-selam by considering urban and rural settings. One health center was selected in each Woreda based on their laboratory facilities. The sample size in each health institution was 150 which was proportionally allocated by considering the population in the catchment areas.

\section{Data collection \\ Questionnaires}

A structured questionnaire was used to obtain sociodemographic information and determinant factors by interviewing pregnant women. The questionnaire was filled by midwifery health professionals.

\section{Haemoglobin determination}

The blood samples were collected from a finger prick by blood lancet. Haemoglobin ( $\mathrm{Hgb})$ value was determined using a portable $\mathrm{Hgb}$ spectrophotometer, Hemocue $\mathrm{Hb}$ 201 analyzer (HemoCue, Angelholm, Sweden) and specially designed microcuvette (the Hemocue $\mathrm{Hb} 201$ Microcuvette, Hemocue, Angelholm, Sweden). Then, the $\mathrm{Hgb}$ value was then used to assess the status of anaemia.
For Hgb the cutoff criterion levels below which indicating aneamia is the WHO cut-off of $>110 \mathrm{~g} / \mathrm{L}$ for non anemic, $100-109 \mathrm{~g} / \mathrm{L}$ for mild anemic, $70-90 \mathrm{~g} / \mathrm{dL}$ moderate and $<70 \mathrm{~g} / \mathrm{dL}$ for severe anemic for pregnant women [2].

\section{Intestinal parasites investigation}

Freshly passed stool specimens were collected using a clean plastic cup at the health institutions. The stool cups were labeled with their card number. Laboratory professionals took part in all processes of stool collection and examination. The stool samples were processed for microscopic examination using Formol Ether Concentration Technique (FECT). The stool examination was done in the health institutions laboratory. In FECT, stool sample $(0.5 \mathrm{~g})$ was transferred into $10 \mathrm{~mL}$ of normal saline in a glass container and mix thoroughly. Two layers of gauze were placed in a funnel and strained the contents into a $15 \mathrm{~mL}$ centrifuge tube. Then, $2.5 \mathrm{~mL}$ of $10 \%$ formaldehyde and $1 \mathrm{~mL}$ of ether were added to a test tube. The test tubes were mixed well and centrifuged at $1000 \mathrm{rpm}$ for three minutes. The supernatant was removed and the sediment was mixed well, prepared on two slides one for saline and the other for iodine, and covered with a cover slide and sow under microscope.

\section{Data quality assurance}

To ensure reliable data collection, training on data collection, laboratory examination and explanation about the study was given before sample collection for midwifery and laboratory personnel. Filled questionnaires were collected after checking for their consistency and completeness. Application of standard procedures during data collection process and accuracy of test results was supervised by the principal investigator. Specimens were cross checked by principal investigators to increase the accuracy of laboratory results. The direct stool microscopy was examined earlier to FECT as soon as the sample arrives. To eliminate observer bias, stool slides were examined independently with two experienced laboratory professionals and $10 \%$ of the FECT slides were randomly selected and read by other laboratory professionals as a quality control.

\section{Data analysis}

Data was entered and analyzed using SPSS version 23 statistical software. The overall magnitude of geohelminthic infection was calculated using descriptive statistics of the sample through frequencies and cross tabulations. Strength of association between geohelminthic and determinant factors was calculated by bivariate analysis. The association was analyzed by multivariate logistic regression to avoid confounding effect and calculating the odds ratios (OR) with 95\% 
confidence intervals $(\mathrm{CI})$. In all statistical tests, the differences were considered to be statistically significant if $p$-value less than 0.05 .

\section{Ethical consideration}

The proposal was ethically approved by an institutional review board of Bahir Dar University, College of Medicine and Health Science. A written informed consent was obtained from every study participant. Participants tested positive for any parasitic infections got appropriate treatment accordingly from the responsible body.

\section{Results}

\section{Sociodemographic characteristics of the study subjects}

A total of 743 pregnant women took part in this study with a median age of 25 years. The majority (96.2\%) of study participants was in the age range 15-35 years. Pregnant women who were rural dwellers and farmers in their occupation accounted $61.2 \%$ ) and $21.5 \%$, respectively (Table 1 ).

\section{Prevalence of anaemia}

The mean Hgb concentration was $12.8 \pm 2.97 \mathrm{~g} / \mathrm{dL}$ with a range of 6 to $17.9 \mathrm{~g} / \mathrm{dL}$. The total prevalence of anaemia among pregnant women was 79 (10.6\%). The prevalence of mild, moderate and severe anaemia was
9.4, 0.4 and $0.1 \%$, respectively. Mild anaemia had high prevalence 77 (97.5\%) among anaemic pregnant women (Table 2).

\section{Prevalence of intestinal parasitosis}

The overall prevalence of intestinal parasitosis among pregnant women was 276 (37.1\%). Hookworm has the highest prevalence 138 (50\%) among the parasitic infected pregnant women followed by E. histolytica 113 (40.9\%) and G. lamblia 53 (19.2\%) (Table 2). The prevalence of anaemia among hookworm, E.histolytica/dipar and G. lamblia infected pregnant women were 39 (28.3\%), $28(24.8 \%)$ and $23(43.4 \%)$, respectively (Table 2 ).

\section{Obstetrics and medical condition of study participants}

There were 509 (68.5\%) multi gravid and 420 (56.5\%) second trimester pregnancy study participants. The prevalence of anaemia among Multi gravid, one parity and third trimester were 57 (11.2\%), 21 (13.2\%) and 31 (13.4\%), respectively. The prevalence of anaemia was 77.8 and $18.1 \%$ among pregnant women who had a previous malaria attack and history of intestinal parasitic infection, respectively (Table 3 ).

Table 1 Socio demographic characteristics of pregnant women who attended ANC services in West Gojjam Zone, Northwest

\begin{tabular}{|c|c|c|c|c|c|}
\hline Variables & & $\begin{array}{l}\text { Total } \\
{[\mathrm{N}, \%]}\end{array}$ & $\mathrm{Hgb}>11 \mathrm{~g} / \mathrm{dL}$ & $\begin{array}{l}\mathrm{Hgb}<11 \mathrm{~g} / \mathrm{dL} \\
{[\mathrm{N}, \%]}\end{array}$ & $x^{2}, p$-value \\
\hline \multirow[t]{2}{*}{ Age in years } & $15-35$ & 715 [96.2] & $646[90.3]$ & $69[9.7]$ & $19.20,0.001$ \\
\hline & $36-45$ & $28[3.8]$ & 18 [64.3] & 10 [35.7] & \\
\hline \multirow[t]{2}{*}{ Religion } & Christian & 736 [99] & 657 [89.3] & 79 [10.7] & NA \\
\hline & Muslim & $7[1]$ & 7 [100] & 0 & \\
\hline \multirow[t]{2}{*}{ Residence } & Rural & 455 [61.2] & $383[88.4]$ & 72 [11.6] & $7.73,0.001$ \\
\hline & Urban & 288 [38.8] & $281[97.6]$ & $7[2.4]$ & \\
\hline \multirow{5}{*}{$\begin{array}{l}\text { Woreda of } \\
\text { West Gojam }\end{array}$} & Fenote Selam & 150 [20.2] & 108 [72] & $42[28]$ & $64.91,0.001$ \\
\hline & Jabitihenane & 151 [20.3] & 143 [94.7] & $8[5.3]$ & \\
\hline & Bure & 142 [19.1] & 133 [93.7] & $9[6.3]$ & \\
\hline & Debub Achefer & 150 [20.2] & 134 [89.3] & 16 [10.7] & \\
\hline & Mecha & 150 [20.2] & $146[97.3$ & $4[2.7]$ & \\
\hline \multirow[t]{2}{*}{ Occupation } & Farmer & 160 [21.5] & 130 [81.3] & 30 [18.7] & $14.10,0.001$ \\
\hline & Non-Farmer & 583 [91.6] & 534 [71.9] & $49[8.4]$ & \\
\hline \multirow[t]{6}{*}{ Education } & Illiterate & $372[50.1]$ & 308 [82.8] & 64 [17.2] & $17.79,0.04$ \\
\hline & Read \& Write & 205 [27.6] & 203 [99] & $2[1]$ & \\
\hline & Primary & 88 [11.4] & $82[97.6]$ & $6[2.4]$ & \\
\hline & Junior & $9[1.2]$ & $8[88.9]$ & $1[11.1]$ & \\
\hline & Secondary & 80 [10.8] & 75 [93.6] & $5[6.4]$ & \\
\hline & > complete & $20[2.7]$ & 19 [95] & $1[5]$ & \\
\hline Total & & 743 [100] & $664[89.4]$ & 79 [10.6] & \\
\hline
\end{tabular}


Table 2 The level of anaemia and intestinal parasitic infection among pregnant women in West Gojjam, Northwest Ethiopia

\begin{tabular}{|c|c|c|c|c|c|c|c|}
\hline \multirow[t]{2}{*}{ Types of IP } & & \multirow[b]{2}{*}{$\begin{array}{l}\text { Total } \\
{[\mathrm{N}, \%]}\end{array}$} & \multicolumn{5}{|l|}{ Level of anaemia } \\
\hline & & & Non-anaemic [N,\%] & $\begin{array}{l}\text { Mild } \\
{[\mathrm{N}, \%]}\end{array}$ & $\begin{array}{l}\text { Moderate } \\
{[\mathrm{N}, \%]}\end{array}$ & $\begin{array}{l}\text { Severe } \\
{[\mathrm{N}, \%]}\end{array}$ & $\begin{array}{l}\text { Total anaemia } \\
{[\mathrm{N}, \%]}\end{array}$ \\
\hline \multirow[t]{2}{*}{ Hookworm } & Pos & $138[18.6]$ & 99 [71.7] & $39[28.3]$ & 0 & 0 & $39[5.2]$ \\
\hline & Neg & $605[81.4]$ & $565[93.4]$ & $38[6.2]$ & $1[0.2]$ & $1[0.2]$ & $40[5.4]$ \\
\hline \multirow[t]{2}{*}{ G. lamblia } & Pos & $53[7.1]$ & $30[56.6]$ & $23[43.4]$ & 0 & 0 & $23[3.1]$ \\
\hline & Neg & $690[93.2]$ & $634[91.8]$ & $54[7.8]$ & $1[0.2]$ & $1[0.2]$ & $56[7.5]$ \\
\hline \multirow[t]{2}{*}{ E. histolytica } & Pos & 113 [15.2] & 85 [75.2] & 26 [23] & $1[0.9]$ & $1[0.9]$ & $28[3.8]$ \\
\hline & Neg & $630[84.8]$ & 579 [91.9] & $51[8.1]$ & 0 & 0 & $51[6.8]$ \\
\hline \multirow[t]{2}{*}{ All Parasite } & Pos & $278[37.4]$ & $222[79.9]$ & 55 [19.8] & $1[0.3]$ & 0 & $56[7.5]$ \\
\hline & Neg & $465[62.6]$ & $442[95.1]$ & $20[4.3]$ & $2[0.4]$ & $1[0.2]$ & $23[3.1]$ \\
\hline Total & & 743 [100] & 743 [100] & $664[89.4]$ & 75 [10.1] & $3[0.4]$ & $1[0.1]$ \\
\hline
\end{tabular}

Pos Positive; Neg Negative

\section{Determinant factors for anaemia in pregnancy}

Pregnant women in rural areas were 3.72 times more likely to be anaemic than urban dwellers $(\mathrm{AOR}=3.72$ [95\%CI:1.51-9.18]). Likewise, farmer pregnant women were 3.51 times more likely to be anaemic with nonfarmer ones $(\mathrm{AOR}=3.51$ [95\%CI:1.75-7.01]). In the same way, non previously medically ill pregnant women were $85 \%$ less likely to be anaemic than previously medically ill ones (AOR $=0.15[95 \%$ CI:0.08-0.28]. Pregnant women who did not eat raw vegetables were 8.94 times more likely to become anemic than pregnant women who ate raw vegetables (AOR $=8.94$ [95\%C:2.86-10.55]). Pregnant women who didn't eat meat were 11.49 times more likely to be anaemic than those who ate meat $(\mathrm{AOR}=11.49$ [95\% CI:2.51-12.53]) (Table 4). Illiterate
Pregnant women were 2.25 times more likely become anaemic than not the illiterate once $(\mathrm{AOR}=2.25$ [95\%CI:1.13-4.48]). Those pregnant women infected with hookworm parasites were 3.81 times more likely to develop anaemia than pregnant women who were not infected with hookworm parasites $(\mathrm{AOR}=3.81[95 \% \mathrm{CI}$, 2.06-7.06]) (Table 4).

\section{Discussion}

Anaemia is an important complication during pregnancy, especially in a rural set up. The impacts of anaemia rest upon not only on the health of pregnant women, but also on her offspring. In the present study, the overall magnitude of anaemia among pregnant women was $10.6 \%$. This result was comparable with

Table 3 Obstetrical \& Medical characteristics of pregnant women who attended ANC service in West Gojjam Zone, Northwest Ethiopia

\begin{tabular}{|c|c|c|c|c|c|}
\hline Variables & & Frequency [N,\%] & $\mathrm{Hgb}>11 \mathrm{~g} / \mathrm{dL}[\mathrm{N}, \%]$ & $\mathrm{Hgb}<11 \mathrm{~g} / \mathrm{dL}[\mathrm{N}, \%]$ & $x^{2}, p$-value \\
\hline \multirow[t]{2}{*}{ Gravidity } & Primigravida & $234[31.5]$ & $212[90.6]$ & $22[9.4]$ & $0.55,0.52$ \\
\hline & Multi gravid & $509[68.5]$ & $457[88.8]$ & $57[11.2]$ & \\
\hline \multirow[t]{4}{*}{ Parity } & No & $241[32.4]$ & $218[90.5]$ & $23[9.5]$ & $1.48,0.69$ \\
\hline & 1 & $159[21.4]$ & $138[86.8]$ & $21[13.2]$ & \\
\hline & $2-3$ & $224[30.2]$ & $201[89.7]$ & $23[10.3]$ & \\
\hline & $>4$ & $119[16]$ & $107[89.9]$ & $12[10.1]$ & \\
\hline \multirow[t]{3}{*}{ Trimester } & First & $142[19]$ & $135[95.1]$ & $7[4.9]$ & $7.22,0.30$ \\
\hline & Second & $326[44]$ & $285[87.4]$ & $41[12.6]$ & \\
\hline & Third & $275[37]$ & $244[88.7]$ & 31 [11.3] & \\
\hline \multirow[t]{2}{*}{ History of malaria infection } & Yes & $9[1.2]$ & $2[22.2]$ & $7[77.8]$ & $43.22,0.00$ \\
\hline & No & 734 [98.8] & $662[90.2]$ & $72[9.8]$ & \\
\hline \multirow[t]{2}{*}{ History intestinal parasite infection } & Yes & $276[37.1]$ & 226 [18.9] & $50[18.1]$ & $25.88,0.00$ \\
\hline & No & $467[62.9]$ & $428[93.8]$ & $29[6.2]$ & \\
\hline \multirow[t]{2}{*}{ History of previous illness } & Yes & 115 [15.5] & $72[62.6]$ & $43[37.4]$ & $24.14,0.00$ \\
\hline & No & $628[84.5]$ & $592[94.3]$ & $36[5.7]$ & \\
\hline
\end{tabular}


Table 4 Multivariate analysis showing the Determinant factors of anaemia among pregnant women in West Gojjam zone, 2017

\begin{tabular}{|c|c|c|c|c|c|c|}
\hline \multirow[t]{2}{*}{ Variables } & & \multicolumn{2}{|c|}{ Anemia present } & \multirow[t]{2}{*}{ COR[95\%Cl] } & \multirow[t]{2}{*}{ AOR[95\%Cl] } & \multirow[t]{2}{*}{$P$ value } \\
\hline & & Yes (N) & No $(\mathrm{N})$ & & & \\
\hline \multirow[t]{2}{*}{ Address } & Rural & 72 & 383 & $7.55[3.42-.16 .65]$ & $3.72[1.51-9.18]$ & 0.004 \\
\hline & Urban & 7 & 281 & 1 & 1 & \\
\hline \multirow[t]{2}{*}{ Occupation } & Farmer & 30 & 130 & $2.52[1.54-4.12]$ & $3.51[1.75-7.01]$ & 0.001 \\
\hline & Non Farmer & 49 & 534 & 1 & 1 & \\
\hline \multirow[t]{2}{*}{ Eating raw vegetables } & No & 75 & 490 & $6.66[2.40-18.47]$ & $8.94[2.86-10.53]$ & 0.001 \\
\hline & Yes & 4 & 174 & 1 & 1 & \\
\hline \multirow[t]{2}{*}{ Age } & $15-35$ & 69 & 646 & 1 & & \\
\hline & $36-45$ & 10 & 18 & $5.20[2.31-11.71$ & $4.46[1.57-12.69]$ & 0.005 \\
\hline \multirow[t]{2}{*}{ Eating meat } & No & 76 & 568 & $4.28[1.32-13.88]$ & $11.49[2.51-12.53]$ & 0.002 \\
\hline & Yes & 3 & 96 & 1 & & \\
\hline \multirow[t]{2}{*}{ Previous illness } & Yes & 43 & 72 & $9.82[5.92-16.29]$ & $0.15[0.08-0.28]$ & 0.001 \\
\hline & No & 36 & 592 & 1 & 1 & \\
\hline \multirow[t]{2}{*}{ Educational status } & Illiterate & 64 & 308 & $4.93[2.75-8.83]$ & $2.25[1.13-4.48]$ & 0.02 \\
\hline & Not illiterate & 15 & 356 & 1 & 1 & \\
\hline \multirow[t]{2}{*}{ Hookworm infection } & Yes & 41 & 97 & $6.31[3.86-10.31]$ & $3.81[2.06-7.06]$ & 0.001 \\
\hline & No & 38 & 567 & 1 & 1 & \\
\hline
\end{tabular}

previous studies done in Amhara Regional State (15.89\%) [11], Gondar city (16.6\%) [12] and Iran (13.1\%) [13]. The current prevalence was also considerably lower than previous reports from Jimma, Southern Ethiopia (38.2\%) [14], Tigray (36.1\%) [15], Southern Ethiopia (23.2\%) [16], Jordan (34.7\%) [17], Vietnam (43.2\%) [18] , and Southeastern Nigeria (76.9\%) [19]. The possible explanation for the difference might be geographical variation of factors across different areas. The lower prevalence in the present study could be attributed to gradual improvement of lifestyle and living standards and health seeking behavior by the effort of government to achieve the sustainable development goal aimed to reduce the maternal mortality.

In the present study, most of the anaemic pregnant women had mild anaemia. This finding was comparable with a result obtained previously in Northwest Ethiopia [20, 21], Southeast Ethiopia [22] and Pakistan [23], but different from other reports [24]. The difference may be due to a regular supply of iron and folic acid supplimentation and anti-helminthic drugs in the present study.

Parasitic infection has a devastating effect on the level of $\mathrm{Hgb}$ and causes anaemia since they affect iron absorption by the intestine and consumes the red blood cells [25]. In the present study, pregnant women who had previous medical illness, malaria infection and intestinal parasitic infection were more likely to become anaemic. This was consistent with previously conducted in Southern Ethiopia [16], Ghana [25], Nigeria [26], and Venezuela [27].

The level of Hgb may be varied during the course of pregnancy by several obstetric factors. In the present study, the level of Hgb is varied by gravidity, parity and trimesters. This result was similar with different findings conducted previously in Southern Ethiopia [16], Southeast Ethiopia [22], Ghana [25] and Iran [28].

In the current study, pregnant women living in rural areas were 3.72 times more likely to be anaemic as compared to those living in urban areas. Similar results were reported by studies conducted in Gondar [12], and southwest Ethiopia [22]. The possible reason might be due to low socioeconomic status, lack of adequate information about nutrition during pregnancy and accessibility to health care facilities and illiteracy.

Lack of awareness about anaemia and its impact during pregnancy may be a major factor becoming anaemic of pregnant women. In the present study, farmer pregnant women were 3.51 times more likely to be anaemic with that of non farmer pregnant women. A similar result was obtained in a study done in India [29]. Pregnant women who did not get formal education were 2.25 times more likely for anaemic than from those who got formal education. Similar findings were reported in India [19] and China [30].

Pregnant women who did not eat raw vegetables were 8.94 times more likely to have anemia compared to pregnant women who eat raw vegetables. This finding is consistent with different parts of Ethiopia [20, 31, 32]. The possible reason might be due to poor dietary diversity which leads to a deficiency of minerals and vitamins which may increase bio-availability of iron. Pregnancy is the most nutritionally demanding period in a woman's 
life. Consequently, pregnant women are advised to eat a more diversified diet than usual.

Pregnant women who didn't eat meat were 11.49 times more likely to be anaemic than those who eat meat. This finding was consistent with other studies in which pregnant women conducted in Ethiopia who ate red meat [31, 32] and Pakistan [23]. The increased concentration of $\mathrm{Hgb}$ is with the fact that red meat is an important source of heme iron [33] which is a major component of red blood cells.

Soil transmitted helminths like hookworm infection causes anaemia during pregnancy. In the current study, pregnant women infected with hookworm parasites were 3.81 times more anaemic than non hookworm infected pregnant women. This finding was consistent with previous studies conducted among pregnant women in East Wollega, Oromia, Ethiopia [34] and Northwest Ethiopia [35]. This study did not include all health institutions due to the absence of full antenatal care service including detection of intestinal parasitosis and determination of the Hgb level.

\section{Conclusion}

Anaemia is one of the major complications during pregnancy. Most pregnant women had mild anaemia in the present study. Factors related to obstetric conditions, nutrition, parasitic infection were the main risk factors. Therefore, awareness should be built among pregnant women targeting on their feeding habits, parasitic infection and hygienic conditions to minimize the outcomes of anaemia during pregnancy.

\section{Abbreviations}

FECT: Formol Ether Concentration Technique; Hgb: Haemoglobin

\section{Acknowledgements}

We should like to thank the Amhara Regional Health Bureau and West Gojjam health office for their invaluable collaboration and support in the undertaking of this study. We are most grateful to thank the head of health institutions in facilitating the pregnant women participation.

\section{Authors' contributions}

TH carried out developing the proposal, data entry, analysis, writes up, and editing the manuscript. SK participated in developing, reviewing and editing the proposal and data analysis and editing of the manuscript. BA involved in evaluating the proposal, and critically reviewing and editing the manuscript. WM involved in critically reviewing and evaluating the proposal and reviewing and editing the manuscript. AG involved in reviewing, editing the proposal and the manuscript. All authors read and approved the final manuscript.

\section{Funding}

The research project was funded by Bahir Dar University.

\section{Availability of data and materials}

To generate findings of this particular study, data was collected and analyzed.
Ethics approval and consent to participate

To conduct this research, the research proposal was ethically approved by the research and ethical review committee of Bahir Dar University, College of Medicine and Health Sciences.

\section{Consent for publication}

Not applicable.

\section{Competing interests}

The authors declare that they have no competing interests.

\section{Author details}

${ }^{1}$ Department of Medical Laboratory Science, College of Medicine and Health Sciences, Bahir Dar University, P.O. Box: 79, Bahir Dar City, Ethiopia.

${ }^{2}$ Department of Midwifery, College of Medicine and Health Sciences, Bahir Dar University, P.O. Box: 79, Bahir Dar City, Ethiopia. ${ }^{3}$ Department of Pharmacy, College of Medicine and Health Sciences, Bahir Dar University, P.O. Box: 79, Bahir Dar City, Ethiopia.

Received: 13 March 2019 Accepted: 1 July 2019

Published online: 17 July 2019

\section{References}

1. De Maeyer EM, Dallman P, Gurney JM, Hallberg L, Sood SK, Srikantia SG. Preventing and controlling iron deficiency anemia through primary health care, a guide for health administrators and programme managers; 1989.

2. Hemoglobin concentration for the diagnosis of anemia and assessment of severity, https://www.who.int/vmnis/indicators/haemoglobin.pdf: World Health Organization; 2011

3. Stephenson LS, Latham MC, Ottesen EA. Malnutrition and parasitic helminth infections. Parasitology. 2000;121:23-38.

4. Obiamuiwe BA, Nmorsi P. Human gastro-intestinal parasites in Bendel State, Nigeria. Nig J Parasitol. 1990;32:177-83.

5. Khor GL. Update on the prevalence of malnutrition among children in NMCJ, vol. 5; 2003. p. 113-22.

6. Okafor IM, Okpokam DC, Antai AB, Usanga EA. Iron Status of Pregnant Women in Rural and Urban Communities of Cross River State, South-South Nigeria. Nig J Physiol Sci. 2017;31:121-5.

7. Diamond-Smith NG, Gupta M, Kaur M, Kumar R. Determinants of Persistent Anemia in Poor, Urban Pregnant Women of Chandigarh City, North India: A Mixed Method Approach. Food Nutr Bull. 2016;37:132-43.

8. Taner CE, Ekin A, Solmaz U, Gezer C, Çetin B, Keleşoğlu M, Merve Bayrak Erpala MB, Özeren M. Prevalence and risk factors of anemia among pregnant women attending a high-volume tertiary care center for delivery. J Turk Ger Gynecol Assoc. 2015;16:231-6.

9. Berhane Y, Gossaye Y, Emmelin M, Hogberg H. Women's Health in Rura Setting in Societal Transition in Ethiopia. Soc Sci Med. 2001;53:1525-39.

10. Jennings J, Hirbaye MB. Review of Incorporation of Essential Nutrition Actions into Public Health Programs in Ethiopia, the food and nutrition technical assistance project, 2008. https://www.fantaproject.org/.../FANTAReview-Incorporation-ENA-Ja.

11. Kassa GM, Muche AA, Berhe AK, Fekadu GA. Prevalence and determinants of anemia among pregnant women in Ethiopia; a systematic review and meta-analysis. BMC Hematolology. 2017;17:17.

12. Alem M, Enawgaw B, Gelaw A, Kena T, Seid M, Olkeba Y. Prevalence of anemia and associated risk factors among pregnant women attending antenatal care in Azezo Health Center Gondar town, Northwest Ethiopia. Interdiscipl Histopathol. 2013;1:137-44.

13. Barooti E, Rezazadehkermani M, Sadeghirad B, Motaghipisheh S, Tayeri S, Arabi M, Salahi S, Haghdoost A. Prevalence of Iron Deficiency Anemia among Iranian Pregnant Women; a Systematic Review and Meta-analysis. J Reprod Infertil. 2010;11:17-24.

14. Belachew T, Legesse $Y$. Risk factors for anemia among pregnant women attending antenatal clinic at Jimma University Hospital, southwest Ethiopia. Ethiop Med J. 2006:44:211-20.

15. Gebre A, Mulugeta A. Prevalence of Anemia and Associated Factors among Pregnant Women in North Western Zone of Tigray, Northern Ethiopia: A Cross-Sectional Study. J Nut Metab 2015;2015:7.

16. Lebso M, Anato A, Loha E. Prevalence of anemia and associated factors among pregnant women in Southern Ethiopia: A community based crosssectional study. PLOS ONE. 2017;12:e0188783. 
17. Al-Mehaisen L, Khader Y, Al-Kuran O, Abu Issa F, Amarin Z. Maternal anemia in rural Jordan: room for improvement. Anemia. 2011;2011:7.

18. Uneke CJ, Duhlinska DD, Igbinedion EB. Prevalence and public-health significance of HIV infection and anaemia among pregnant women attending antenatal clinics in southeastern Nigeria. J Health Popul Nutr. 2007;25:328-35.

19. Levy A, Fraser D, Katz M, Mazor M, Sheiner E. Maternal anemia during pregnancy is an independent risk factor for low birth weight and preterm delivery. Eur J Obstet Gynecol Reprod Biol. 2005;122:182-6.

20. Derso T, Abera Z, Tariku A. Magnitude and associated factors of anemia among pregnant women in Dera District: a cross-sectional study in northwest Ethiopia. BMC Res Notes. 2017;10:359.

21. Melku M, Addis Z, Alem M, Enawgaw B. Prevalence and Predictors of Maternal Anemia during Pregnancy in Gondar, Northwest Ethiopia: An Institutional Based Cross-Sectional Study. Anemia. 2014;2014:108593.

22. Kefiyalew F, Zemene E, Asres Y, Gedefaw L. Anemia among pregnant women in Southeast Ethiopia: prevalence, severity and associated risk factors. BMC Res Notes. 2014;7:771.

23. Baig-Ansari N, Badruddin SH, Karmaliani R, Harris H, Jehan I, Pasha O, Moss N, McClure EM, Goldenberg RL. Anemia prevalence and risk factors in pregnant women in an urban area of Pakistan. Food Nutr Bull. 2008;29:132-9.

24. Gedefaw L, Ayele A, Asres Y, Mossie A. Anemia and Associated Factors Among Pregnant Women Attending Antenatal Care Clinic in Wolayita Sodo Town, Southern Ethiopia. Ethiop J Health Sci. 2015;25:155-62.

25. Tay KSC, Nani EA, Walana W. Parasitic infections and maternal anaemia among expectant mothers in the Dangme East District of Ghana. BMC Res Notes. 2017;10:3

26. Akinbo FO, Olowookere TA, Okaka CE, Oriakhi MO. Co-infection of malaria and intestinal parasites among pregnant women in Edo State, Nigeria. J Med Trop. 2017;19:43-8.

27. Rodríguez-Morales AJ, Barbella AR, Case C, Melissa Arria M, Ravelo M, Perez H, Oscar U, Gervasio G, Rubio N, Maldonado A, Aguilera Y, Viloria A, Blanco JJ, Colina M, Hernández E, Araujo E, Cabaniel G, Benitez J, Rifakis P. Intestina Parasitic Infections among Pregnant Women in Venezuela. Infect Dis Obstet Gynecol 2006;2006:23125.

28. Mirzaie F, Eftekhari N, Goldozeian S, Mahdavinia J. Prevalence of anemia risk factors in pregnant women in Kerman, Iran. Iran J Reprod Med. 2010;8:66-9.

29. Singh V, Rai D, Thakur S, Singh VN. Study of iron deficiency anaemia in farm women of lucknow district in Uttar Pradesh, India. Plant Archives. 2017;17. $125-8$.

30. Ma AG, Schouten E, Wang Y, Li Y, Sun YY, Wang QZ. Anemia prevalence among pregnant women and birth weight in five areas in China. Med Princ Pract. 2009;18:368-72.

31. Gebremedhin S, Enquselassie F. Correlates of anemia among women of reproductive age in Ethiopia: evidence from Ethiopian DHS. Ethiop J Health Dev. 2005:25:22-30.

32. Alene KA, Dohe AM. Prevalence of Anemia and Associated Factors among Pregnant Women in an Urban Area of Eastern Ethiopia. Anemia. 2014:2014:7.

33. Obse N, Mossie A, Fau-Gobena T, Gobena T. Magnitude of anemia and associated risk factors among pregnant women attending antenatal care in Shalla Woreda, West Arsi Zone, Oromia Region, Ethiopia. Ethiop J Health Sci. 2013;23:165-73

34. Mengist HM, Zewdie O, Belew A. Intestinal helminthic infection and anemia among pregnant women attending ante-natal care (ANC) in East Wollega, Oromia. Ethiopia. BMC Res Notes. 2017;10:440.

35. Kumera G, Haile K, Abebe N, Marie T, Eshete T. Anemia and its association with coffee consumption and hookworm infection among pregnant women attending antenatal care at Debre Markos Referral Hospital, Northwest Ethiopia. PLoS One. 2018;13(11):e0206880.

\section{Publisher's Note}

Springer Nature remains neutral with regard to jurisdictional claims in published maps and institutional affiliations.

Ready to submit your research? Choose BMC and benefit from:

- fast, convenient online submission

- thorough peer review by experienced researchers in your field

- rapid publication on acceptance

- support for research data, including large and complex data types

- gold Open Access which fosters wider collaboration and increased citations

- maximum visibility for your research: over $100 \mathrm{M}$ website views per year

At BMC, research is always in progress.

Learn more biomedcentral.com/submissions 